\title{
SECTION 301(a) AND THE FEDERAL COMMON LAW OF LABOR AGREEMENTS
}

Section 301(a) of the Labor Management Relations Act ${ }^{1}$ invests federal district courts with jurisdiction over suits for breach of a collective contract between an employer and a labor organization, irrespective of the amount in controversy or the citizenship of the parties. The primary aim which appears to have motivated this enactment was the desire to promote more responsible labor relations by making both parties to the agreement answerable for its breach in federal court. ${ }^{2}$ The new section was required to circumvent the difficulties involved in suing unions as unincorporated associations. ${ }^{3}$

Although on its face the section remedied only this jurisdictional difficulty, judicial construction has given section $30 \mathrm{l}$ a much broader effect. In Textile Workers Union of America v. Lincoln Millst the union sued under section 301 to compel arbitration of a matter contained in the collective agreement. Unable to find any authority in either state or federal law upon which to grant relief," the Court of

1. The relevant portion of the section states:

Suits for violaton of contracts between an employer and a labor organization representing employees in an industry affecting commerce. . . may be brought in any district court of the United States having jurisdiction of the parties, without respect to the amount in controversy or without regard to the citizenship of the parties.

Labor Management Relations Act (Taft-Hartley Act) § 301(a), 61 Stat. 156 (1917), 29 U.S.C. $\S 185$ (1964).

2. See H.R. Rep. No. 245 , 80th Cong., Ist Sess. $45-46$ (1947); S. Rer. No. 105, 80th Cong., 1st Sess. 15-18 (1947).

3. For a discussion of the status of labor unions for purposes of judicial proceedings see generally Witmer, Trade Union Liability: The Problem of the Unincorporated Corporation, 51 YALE L.J. 40 (1911); Note, The Problem of Capacity in Union Suits: A Potpourri of Erie, Diversity and the Federal Rules of Civil Procedure, 68 YALE L.J. 1182 (1959).

4. 353 U.S. 448 (1957). Commentary on the decision shortly after its rendition include Bunn, Lincoln Mills and the Jurisdiction to Enforce Collective Bargaining Agreements, 43 U. VA. L. REv. 1247 (1957); Feinsinger, Enforcement of Labor Agreements-A New Era in Collective Bargaining, id. at 1261; Note, 43 CorNeLL L.Q. 503 (1958).

5. The difficulty was due to the fact that at common law executory contracts to submit matters to arbitration could not be specifically enforced. The United States Arbitration Act, 9 U.S.C. § 1 (1964), sought to remedy this problem, but the act was expressly made inapplicable to contracts of employment of workers engaged in interstate commerce. The Court of Appeals in Lincoln Mills held the collective bargaining agreement was a "contract of employment," and therefore, that the act was not applicable. 230 F.2d 81, 86 (5th Cir. 1956). Moreover, that court did not view $\S 301$ as yielding anjthing more than an expansion of the jurisdiction of federal courts. "[T]t does not follow that because jurisdiction is given ... there is a new federal law concept that authorizes the courts to cnforce submission to arbitration." Id. at 88. 
Appeals affirmed the District Court's refusal to force arbitration. The Supreme Court reversed in an opinion by Mr. Justice Douglas which held that section 301 was not merely jurisdictional and that "it authorizes federal courts to fashion a body of federal law for the enforcement of . . collective bargaining agreements. . .." His pronouncement, by permitting judicial creation of a new corpus of federal labor law, furnished an authority upon which relief could be granted. He indicated only in broad outline, however, the sources of that law. "[T] he policy of our national labor laws"" was to serve as the primary guide. Provisions of the Labor Management Relations Act were suggested as aids in finding and developing this policy. In addition "state law" could be used to the extent it was compatible with the purposes of section 301.

The source of law problem received additional consideration in subsequent opinions. On several occasions the Court attempted to articulate more precisely the manner in which federal law about collective agreements was to be formulated from national labor policy. ${ }^{8}$ Nevertheless, many lower federal courts have failed to consider the requirements of that policy. ${ }^{9}$ The manifestations of this failure have ranged

\footnotetext{
6. 353 U.S. at 451 .

7. Id. at 456 .

8. Typical of the attempt to elaborate on the task of creating federal labor law is the following:

The dimensions of $\$ 301$ require the conclusion that substantive principles of federal labor law must be paramount in the area covered by the statute. Comprehensiveness is inherent in the process by which the law is to be formulated under the mandate of Lincoln Mills, requiring issues raised in suits of a kind covered by $\S 301$ to be decided according to the precepts of federal labor policy.
}

Local 174, Teamsters Union v. Lucas Flour Co., 369 U.S. 95, 103 (1962). Accord, Smith v. Evening News Ass'n, 371 U.S. 195, 199-200 (1962); Retail Clerks Ass'n v. Lion Dry Goods, Inc., 369 U.S. 17, 27 (1962).

9. Several factors might be advanced in an effort to rationalize this failure. First, it has been argued that because national labor policy is not set forth in an casily accessible, comprehensible form, giving content to that policy is difficult. This problem is even morc pronounced in the area of labor than other fields of governmental regulation. The NLRB, in contrast to other federal administrative agencies, extensively uses its adjudicatory machinery, rarely if ever resorting to rulemaking. As a consequence, case by casc analysis may be necessary to ascertain the Board's position on a given matter. This process is much more demanding than looking to an agency statement formulated through rulcmaking. See Shapiro, The Choice of Rulemaking or Adjudication in the Development of Admin. istrative Policy, 78 HARv. L. REv. 921, 940.41 (1965). But see Friendly, The Fedcral Administrative Agencies: The Need for Better Definition of Standards, 75 Hakv. L. Rev. 863, 891 (1962). See generally Peck, The Atrophied Rule-Making Powers of the National Labor Relations Board, 70 YALE L.J. 729 (1961). Second, it has been argued that the creation of federal law based on national labor policy is an undertaking for which the courts arc institutionally unsuited. This argument has two dimensions. On the one hand, those strains of labor policy that can be identified may, in any given case, reflect competing aims. On the other hand, $\S 301$ itself offers no guidance in the creation of labor contract law. As a 
from an apparent unawareness that labor policy must be examined, ${ }^{10}$ to a token acknowledgment of its relevance. ${ }^{11} \mathrm{~A}$ demonstration of this latter response appears in Genesco, Inc. v. Joint Council 13, United Shoe Workers, ${ }^{12}$ a recent Second Circuit decision. Genesco was a member of a multi-employer bargaining group representing several shoe manufacturers in negotiations to reach a new agreement with a union. Before all the matters in controversy could be resolved, however, the pre-existing agreement lapsed, and a strike was called. Shortly thereafter, a settlement was reached. The union signed individual memoranda of understanding for each employer. A resumption of work followed at all factories but Genesco's. After demanding that the union end its strike, Genesco brought suit for damages caused by breach of the no-strike clause in the alleged collective bargaining agreement. ${ }^{13}$ In reply, the union moved to dismiss on the ground that the company should be forced to arbitrate before bringing suit. Alternatively the union claimed that no bargain had been reached. This latter defense was based on the union's purported imposition of an oral condition precedent which it claimed had been unfulfilled. Genesco maintained that its membership in the multi-employer bargaining group, ${ }^{14}$ with

consequence, in both situations the courts become involved in a complex, undirected task of policy-making which they are both unable and unwilling to undertake. See Bickel \& Wellington, Legislative Purpose and the Judicial Process: The Lincoln Mills Case, 71 HARv. L. REv. 1, 22-29 (1957). But see Summers, Frankfurter, Labor Low and the Judge's Function, 67 YaLE L.J. 266, 292 n.144 (1957), anguing that courts had in fact been making just such decisions for many years. For a consideration of judicial performance under § 301, see generally Comment, The Emergent Federal Common Low of Labor Contracts: A Survey of the Law under Section 301, 28 U. Crit. L. REv. 707 (1961).

10. Calhoun v. Bernard, 333 F.2d 739, 741 (9th Cir. 1964); Burlesque Artists Ass'n v. I. Hirst Enterprises, 267 F.2d 414, 416 (3d Cir. 1959); Local Joint Exce. Bd., Hotel Employees Union v. Nationwide Downtowner Motor Inns, Inc, 229 F. Supp. 413, 416 (W.D. Mo. 1964); International Ass'n of Machinists v. Shawnee Indus., 224 F. Supp. 347, 352 (W.D. Okla. 1963).

11. United Packinghouse Workers v. Maurer-Neuer, Inc., 272 F.2d 647, 619 (10th Cir. 1959), cert. denied, 362 U.S. 904 (1960); Plumbers Union v. Dillion, 255 F.2d 820.823 (9th Cir. 1958).

12. 341 F.2d 482 (2d Cir. 1965).

13. Jurisdiction was alleged both under $\S 301$ and diversity of citizenship. While it seems that the case was litigated solely as a $\S 301$ case, the fact of diversity jurisdiction does not alter the choice of law problem presented. If the action was premised solely on diversity, state law would be applied under Erie. But the state law applied would have to be formulated in the same manner as federal law in a $\$ 301$ case. Local 174. Teamsters Union v. Lucas Flour Co., 369 U.S. 95 (1962), explicitly rejected the proposition that "the courts of the states remain free to apply individualized local rules when called upon to enforce such agreements. . . . The dimensions of $\S 301$ require the conclusion that substantive principles of federal labor law must be paramount in the area covered by the statute." 369 U.S. at 103.

14. For a discussion of the role of multi-emplojer bargaining in labor-management re- 
which the union conceded an agreement, precluded the union from singling Genesco out for the imposition of a special, last minute condition. Viewing the threshold question to be one concerning the existence of the individual agreement with Genesco, the district court ordered a hearing to determine that issue, found for the union, and dismissed the complaint. ${ }^{15}$

A unanimous appellate panel, in an opinion written by Judge Friendly, held that "if the issue is to be determined by applying ordinary principles of contract law, we would conclude that no agreement between the union and Genesco was reached."18 He went on, however, to deal with Genesco's "interesting contention" that federal law, rather than "ordinary principles of contract," should be applied. As he characterized Genesco's argument, courts should find a contract to exist regardless of the parties' intent whenever a refusal to sign a collective agreement would constitute an unfair labor practice. ${ }^{17}$ To consider this position, he distinguished between questions of "formation" and questions of "interpretation." Although he did not fully explain the reasons for such a distinction, ${ }^{18}$ Judge Friendly felt that courts could properly "pass on the same conduct as the NLRB might have to consider in the trial of an unfair labor practice complaint" 10 only regarding questions of "interpretation." He refused to use national labor policy in adjudicating questions of "formation," for to do so would place state and federal courts even further into "the center of the very area, the definition of unfair labor practices, which Congress staked out for the Labor Board. . . ."20 After expressing doubt that the NLR1B would have found an unfair labor practice, Judge Friendly concluded that there were no clear radiations from national labor policy which undermined his initial disposition based on "ordinary principles of contract law."21

\footnotetext{
lations, see generally Note, Multi-Employer Bargaining and the National Labor Relations Board, 66 HARv. L. REv. 886 (1953).

15. The opinion of the district court appears at 230 F. Supp. 923 (S.D.N.Y. 1964).

16. 341 F.2d at 486 .

17. Id. at 487 .

18. The explanation Judge Friendly offers for the distinction is not altogether satisfactory. While he felt that the distinction was unwarranted simply as the result of a "mechanical view that federal power attaches only when a contract has been made," he did think that it had meaning "as a point of substance." Ibid. As a consequence, federal law ought properly to apply only to the interpretation of a collective bargaining agrecment.

19. Id. at 487 .

20. Id. at $487-88$.

21. Id. at 489 .
} 
Judge Friendly attempted to avoid the difficulties of deciding in accord with national labor policy by implying that to do so would interfere with the NLRB.22 This deference in a section 301 case, however, is unjustified.23 The legislative history of the section makes clear that Congress held a contrary attitude about the courts' relationship to the Board. Congress expressly rejected a proposal that the breach of a collective agreement be left to the Board on the ground that actions involving these agreements should be governed by the "usual processes of the law" instead of by the administrative process."- Carey $v$. Westinghouse Electric Corp. ${ }^{25}$ was decided in accordance with this con-

22. Judge Friendly in part also seems to base his deference on the fact that the Board has more extensive remedial powers than a court. He states that

[G]ourts would be forced to decree contract formation . . . in all such cases, although

the Board, with the wide choice of remedies given by $\S 10(c)$ of the Act, might

think a lesser sanction appropriate.

341 F.2d at 488. But there are other judicial expressions which seem to contradict this reasoning. Mr. Justice Harlan, in his concurring opinion in San Dicgo Bldg. Trades Council v. Garmon, 359 U.S. 236, 249-54 (1959) observed that

[S]ince the reparation powers of the Board, as we observed in Russell, are narrowly circumscribed, those injured by nonviolent conduct will often go remediless even when the Board does accept jurisdiction.

Id. at 253. See Local 189, Amalgamated Meat Cutters, AFL-CIO v. Jewel Tea Co., 381 U.S. $676,687-88$ (1965).

23. Usually, resort to the doctrine of primary jurisdiction aids in a determination of the appropriate jurisdictional spheres of courts and administrative agencies in instances where there exists some overlap between the two. For example, Genesco sought to prosecute an unfair labor practice charge against the union as well as the $\$ 301$ action for damages caused by the same conduct. In its pure formulation, the application of the primary jurisdiction doctrine would necessitate judicial abstention until an administrative agency has resolved a question raised in the court proceeding, Uhereby minimizing the prospect of conflict between the tribunals. On this view, there would be two proceedings, one before the NLRB, the other before the court. Professor Sovern, hovever, alter a thorough consideration of the doctrine as it relates to $\$ 301$, concludes

Courts must be permitted to decide contract actions involving conduct "arguably subject to $\S 7$ or $\S 8$ of the Act," even though permitting them to do so rislis an occasional decision disserving rights protected by the NLRA and a modicum of disorder in administration, because a contrary rule probably would cmasculate section 301.

Sovern, Sections 301 and the Primary Jurisdiction of NLRB, 76 HARv. L. REv. 529, 553 (1963). See generally 3 Davis, Admunistrative LAw Treatise $\$ \S 19.01-.09$ (1958); Jaffe, Primary Jurisdiction, if HARv. L. REv. 1037 (1964).

24. When the 1947 labor legislation was before Congress for consideration, there vas a provision in both the House and Senate versions making the breach of a collective bargaining agreement an unfair labor practice subject to the jurisdiction of the NLRB. S. REP. No. 105, 80th Cong., Ist Sess. 20-23 (1947); H.R. REP. No. 245, 80th Cong., Ist Sess. 21 (1947). In conference this provision was dropped and Congress adopted $\$ 301$, thereby relying on the judicial process alone to adjudicate such actions. H.R. CoNr. REP. No. 510, 80 th Cong., lst Sess. 42 (1947).

25. 375 U.S. 261 (1964). 
gressional judgment. Although it was recognized there that aspects of the controversy would almost certainly be raised again in a subsequent Labor Board proceeding, ${ }^{26}$ the Supreme Court nevertheless granted plaintiff's demand for arbitration. ${ }^{27}$ In so doing, the Court pointed out that the NLRB would probably respect the arbitrator's decision. ${ }^{88}$

Other sections of the LMRA provide additional insight into the congressional judgment regarding the respective roles of the courts and the Board. Section 303 grants a civil action for damages to anyone injured as a consequence of those unfair labor practices defined in section $8(\mathrm{~b})(4) .{ }^{29}$ In hearing these suits the court must construe and apply the same provision which the Board considers in an unfair labor practice proceeding. Yet with no hesitation the Supreme Court, in International Longshoremen's Union v. Juneau Spruce Corp., ${ }^{30} \mathrm{de}$ cided that "there is nothing in the language of $\S 303(\mathrm{a})(4)$ which makes its remedy dependent on any prior administrative determination that an unfair labor practice has been committed." 31 The Court's interpretation of the statutory provision must have been based on the conviction that Congress felt no institutional impediments barred a court from independently considering conduct which might also be passed upon by the NLRB.

In addition to disregarding congressional judgment, Judge Friendly ignored the attitude the Supreme Court has taken toward the Board in some recent decisions. Starting with NLRB v. Insurance Agents' $U_{n i o n}{ }^{32}$ the Court began to show its suspicion of the Board's ability to confine its exercise of authority within the proper sphere. As a consequence, the Court refused to allow the Board to "regulate the choice of economic weapons that may be used as part of collective bargaining," fearing "an intrusion into the substantive aspects of the bargaining process." 33 Additional indications of lack of con-

26. The union was seeking arbitration of a dispute as to which of two unions' members was to do certain work. In the view of the Court, a question of either work assignment or representation was involved. Both of these matters are within the jurisdiction of the NLRB; the former under $\S 10(\mathrm{k})$, the latter under $\S 9(\mathrm{c})$. Labor Management Relations Act $\$ \S 9(\mathrm{c}), 10(\mathrm{k}), 61$ Stat. 144,149 (1947), 29 U.S.C. $\$ \S 159(\mathrm{c}), 160(\mathrm{k})(1964)$.

27. The Court explicitly stated that "the existence of a remedy before the Board for an unfair labor practice does not bar individual employees from seeking damages for the breach of a collective bargaining agreement. . . " 375 U.S. at 268.

28. Id. at 270-72.

29. Labor Management Relations Act (Taft-Hartley Act) $\S 303,61$ Stat. 158 (1947), as amended, 73 Stat. 545 (1959), 29 U.S.C. § 187 (1964).

30. 342 U.S. 237 (1952).

31. Id. at 244.

32. 361 U.S. 477 (1960).

33. Id. at 490 . 
fidence in the Board appeared in Fibreboard Paper Products Corp. v. $N L R B^{34}$ where the Court ignored the Board's rationale completely while devising one of its own. Finally, in NLRB v. Brown ${ }^{35}$ and $A$ merican Ship Building Co. v. $N L R B^{36}$ the Court's distrust of the Board was made explicit. While acknowledging the respect due the NLRB's determination of fact, the Court indicated that "the deference owed to an expert tribunal cannot be allowed to slip into a judicial inertia which results in the unauthorized assumption by an agency of major policy decisions. ..." ${ }^{37}$ As these cases make clear, the Supreme Court is unwilling to rely upon the NLRB even in matters which are expressly committed to it, such as the definition of unfair labor practices. $^{38}$ There was less reason for Judge Friendly to defer in actions on collective bargaining agreements, since Congress entrusted these suits to judicial determination exclusively.

Judge Friendly's first mistake in Genesco forced him into a second, perhaps more serious, mistake. The unwarranted deference prevented resort to national labor policy, forcing him to rely upon contract principles as the only alternative source of law. Judge Friendly might have found these principles in one of two places; choosing either source raises important problems. On the one hand, he might have believed that federal law was the source of these contract principles. Such a belief would have required him to interpret section 301 as being a direction to the courts to make federal substantive law without reference to the policies expressed in other sections of the LMRA. But section 301, so interpreted, might be an unconstitutional delegation of legislative power. ${ }^{39}$ Justice Frankfurter, in his dissent in Lincoln Mills, ${ }^{40}$ doubted the legality of delegating power to the courts

\footnotetext{
34. 379 U.S. 203 (1964).

35. 380 U.S. 278 (1965).

36. 380 U.S. 300 (1965).

37. Id. at 318 .

38. See Summers, Labor Law in the Supreme Court: 1964 Term, 75 YALE, L.J. 59, 84-88 (1965).

39. Since the celebrated case of Schechter Poultry Corp. v. United States, 295 U.S. 495 (1935), which struck down the code-making provisions of the NIRA as an unconstitutional delegation of legislative power to the President, the Supreme Court has not found any delegation to be beyond the power of Congress. But subsequent cases, in which attacks on the propriety of a delegation have been made, were explicit in requiring that the delegation be bounded by definite and precise standards. Carlson v. Landon, 342 U.S. 524, 544 (1952); Yakus v. United States, 321 U.S. 414, 426 (1944). Presumably, if $\S 301$ were to be attacked on grounds of being an inadequate delegation to the courts, the requirements established by those cases to uphold a delegation would have to be met. The inadequacy of guidelines accompanying the section, however, might make that task a difficult one.
}

40. 353 U.S. at 460,46469 (1957). 
to formulate a federal law of labor relations using the provisions in existing labor legislation as a guide. ${ }^{41} \mathrm{His}$ doubts were not shared by the majority in that case. The majority resorted to labor legislation in order to create federal law. However, Justice Frankfurter's view poses a more serious obstacle in a case like Genesco where federal law would be created without the guidance of any congressional policy statement.

Alternatively, perhaps Judge Friendly's contract principles were based on state law. Considerable doubts concerning the court's jurisdiction would attend this view. Article III of the Constitution extends the judicial power of the United States to cases arising under the Federal Constitution, laws, and treaties. Congress must have relied upon the phrase "Cases ... arising under the ... Laws of the United States" to sustain the jurisdiction granted in section $301 .^{42}$ But if a federal substantive law is not applied, ${ }^{43}$ Judge Friendly must believe that the mere invocation of section 301 , as a federal jurisdictional statute, satisfies the "arising under" requirement. ${ }^{44}$ At least implicitly he would have to adopt the theory of "protective jurisdiction" as a basis for that section's constitutional validation. ${ }^{45}$ Summarized by Justice Frankfurter in his Lincoln Mills dissent, protective jurisdiction holds

41. Id. at 456-57.

42. Section 301 does not require diversity of citizenship as a basis of jurisdiction. Likewise, it does not rest on explicit constitutional provisions, nor docs it raise questions involving ambassadors or admirality. As a consequence, $\S 301$ cases must arise under the laws of the United States. For a discussion of the constitutional problem attending $\$ 301$, see Mishkin, The Federal 'Question' in the District Courts, 53 CouvM. L. Rev. 157, 184-96 (1953); Wollett \& Wellington, Federalism and Breach of the Labor Agrcement, 7 StAN. L. REv. 445, 446-47 (1955); Note, Section 301(a) of the Taft-Flarlley Act: $A$ Constitutional Problem of Federal Jurisdiction, 57 YALE L.J. 630 (1948).

43. The sources relied upon by Judge Friendly in reaching his decision secm to indicate that he did not resort to federal substantive law. References to state court cases, diversity cases, Corbin and Williston provide the sole support for his conclusion that "by applying ordinary principles of contract law ... no agreement . . . was reached." $341 \mathrm{~F} .2 \mathrm{~d}$ at 486.

44. There is some authority for the proposition that a federal jurisdiction statute alone will not satisfy the "arising under" requirement. Cf., Skelly Oil Co. v. Phillips Petroleum Co., 339 U.S. 667 (1950), holding that an action which invoked the Declaratory Judgment Act did not arise under federal law since the act merely enlarged the remedics available in the federal courts. Similarly, a statute, like $\S 301$, which affords access to the courts does not abrogate the requirement that the claim for relief be based on fecicral substantive law. But one commentator has advanced the position that $\S 301$ actions, when viewed within the context of the LMRA, arise under federal law:

[T]he act means that such agreements become contracts. If that is so, a suit on such

a contract depends upon the act and arises under it, and so is within the judicial power of article III without regard to diverse citizenship.

Bunn, supra note 4 , at 1256 .

45. For a discussion of protective jurisdiction as it related to $\S 301$ see Mishkin, supra note 42 , at $184-96$. 
that in any case for which Congress has the constitutional power to prescribe federal rules of decision and thus confer "true" federal question jurisdiction, it may, without so doing, enact a jurisdictional statute, which will provide a federal forum for the application of state statute and decisional law. ${ }^{16}$

Since Congress could have legislated a comprehensive code governing collective bargaining agreements under the commerce power, but instead passed only a jurisdictional statute, the conditions for protective jurisdiction are met. ${ }^{47}$ The decision in Genesco, if rooted in state law, therefore, would raise the question of the propriety of using protective jurisdiction to sustain section 301.

It is clear that Lincoln Mills cannot be cited to support a theory of protective jurisdiction, for in that case the Court created and applied federal substantive law. ${ }^{48}$ This application of federal common law satisfied the "arising under" requirement of Article III," making it unnecessary for the Court to resort to more attenuated doctrines to sustain section $301 . .^{50} \mathrm{Had}$ the Court dealt explicitly with protective

46. 353 U.S. at 473 .

47. An analogous situation in which protective jurisdiction arguably has been excreised involves $\$ 70(\mathrm{e})$ of the Bankruptcy Act, 30 Stat. 566 (1898), as amended, 11 U.S.C. $\$ 110(c)$ (1964). Under that provision, a trustee can pursue in a federal forum a cause of action arising under and governed by state law. It might be argued, however, that the Bankruptcy Act itself gives the trustee the status to sue in federal court, thereby investing him with a federal right which arises under a federal law. In another analogous situation, the Supreme Court upheld the exercise of federal jurisdiction in a contract action involving a federally incorporated bank. Osborn v. Bank of the United States, 22 U.S. ( 9 Wheat.) 738 (1824). Subsequently federal jurisdiction was upheld in actions against federally chartered railroad corporations. Pacific Railroad Removal Cases, 115 U.S. 1 (1885). These cases were held to "arise under" the federal laws even though the matter at issuc was likely to be governed by state law. In both situations, however, there existed the possibility that an aspect of a congressional enactment might be challenged, sufficient to pose a potential federal question satisfying article III.

48. 353 U.S. 448,456 (1957).

49. Judges and commentators have acknowledged the possibility of satisfying Article III by creating federal common Iaw. In United States v. Standard Oil Co., 332 U.S. 301 (1947), the Court recognized that "there remains what may be termed . . . an area of 'federal common law" ... outside the constitutional realm. ..." Id. at 303. Once the ability to create federal common law is conceded, reference to "laws" in Article III would encompass both legislative and judicial lawmaking. While no court has yet squarely held that this body of federal common law satisfies the "arising under" requirement of Article $\mathrm{WI}$, Justice Brennan, in two dissenting opinions, argued strongly in favor of that proposition. Wheeldin v. Wheeler, 373 U.S. 647, 663-65 (1963); Romero v. Int'l Terminal Operating Co., 358 U.S. 354, 393 (1959). See Kurland, The Romero Case and Some Problems of Federal Jurisdiction, 73 HARv. L. REv. 817, $831-33$ (1960); Moore, Federalism and Foreign Relations, 1965 DUFe L.J. 249, 291-297; Note, Federal Cammon Law and Arlicle III: A Jurisdictional Approach to Erie, 74 Yale L.J. 325, $330-31$ (1904).

50. For a consideration of the possible alternative theses supporting $\S 301$ jurisdiction see Mendelsohn, Enforceability of Arbitration Agreements under Tafl-Harlley Section 301, 
jurisdiction, it would have been rejected for two reasons. First, assuming that the Court would have maintained its position on the desirability of federal courts fashioning a federal law of labor relations, a holding that section 301 is grounded in both "true" federal question and protective jurisdiction would require the development of a distinction between those questions to be governed by federal law and those to be governed by state law. Yet, neither section 301 nor the cases interpreting it give the slightest indication that Congress contemplated this distinction. Moreover, the language of the Lincoln Mills opinion seems to preclude the bifurcation of that section.

Federal interpretation of the federal law will govern, not state law. ... Any state law applied ... . will be absorbed as federal law and will not be an independent source of private rights. ${ }^{51}$

And second, the need for a uniform federal labor law ${ }^{62}$ would militate against the application of state law under a protective jurisdiction theory. A resort to such a theory would yield a body of law which differed according to the substantive law of the state in which the federal court was sitting.

The Supreme Court, recognizing the propriety of using federal labor policy in a suit under section 301 , but also recognizing the difficulty of fashioning proper rules, has employed a federal rule in favor of the resolution of labor contract disputes by arbitration. ${ }^{53}$ Since the Steelworkers Trilogy, ${ }^{54}$ the Court has construed national labor policy to require arbitration, whenever possible, to attain the desired goals

66 YALE L.J. 167, 190-94 (1956). This article was cited by Justice Douglas in the majority opinion in Lincoln Mills immediately after his conclusion that federal law based on national labor policy must be applied in a $\$ 301$ action. 353 U.S. 448, 456.57 (1957).

51. Id. at 457 .

52. See Local 174, Teamsters Union v. Lucas Flour Co., 369 U.S. 95 (1962). That case involved the issue of whether a state court hearing a \& 301 type action should apply state or federal law. As the Court there indicated:

[T] he subject matter of $\S 301$ (a) "is peculiarly one that calls for uniform law." . . . The possibility that individual contract terms might have different meanings under state and federal law would inevitably exert a disruptive influence upon both the negotiation and administration of collective agreements. . . . The importance of the area which would be affected ... makes the need for a single body of federal law particularly compelling.

Id. at 103-04. But see International Union, U.A.W. v. Hoosier Cardinal Corp., 86 Sup. Ct. 1107 (1966), where the Supreme Court applied a state statute of limitations in a section 801 action.

53. See Smith and Jones, The Supreme Court and Labor Dispute Arbitration: The Emerging Federal Law, 63 Mich. L. REv. 751, 757-58 (1965).

54. United Steelworkers v. Enterprise Wheel \& Car Corp., 363 U.S. 593 (1960); United Steelworkers v. Warrior \& Gulf Nav. Co., 363 U.S. 574 (1960); United Steclworkers v. American Mfg. Co., 363 U.S. 564 (1960). 
in labor-management relations. ${ }^{55}$ The derivation of the arbitration rule from congressional policy statements avoids the delegation problem inherent in Judge Friendly's reliance upon ordinary contract principles. In addition, the jurisdictional problem of Genesco is avoided, since a court is applying a federal rule when it requires arbitration.

Sometimes, however, the rule favoring arbitration cannot be invoked. Clearly, those cases in which the collective agreement contains no arbitration clause present this possibility. And cases like Genesco, where the formation of the contract is at issue, cannot be decided by resort to arbitration unless the arbitrator is allowed to determine the existence of the collective bargaining agreement. Several serious obstacles may, however, prevent him from undertaking such "jurisdictional arbitration."56

The arbitrator's power traditionally derives from the agreement by the parties to submit questions to him. Allowing the arbitrator to resolve issues of contract formation, however, would reverse this relationship, permitting him to impose himself upon the parties. Since the decision of an arbitrator is likely to be conclusive, ${ }^{57}$ a court ought to make certain prior to ordering arbitration that the parties opted for that method of settling disputes. A consideration of the arbitrator's position also weighs against "jurisdictional arbitration." $\mathrm{He}$ may not be a wholly disinterested party. He may be biased to find a contract exists, for by so doing he can assure himself arbitration fees in later disputes concerning the same agreement. ${ }^{68}$

55. Id. at 568, 585, 596.

56. "Jurisdictional arbitration" is used to indicate that the arbitrator, whose power to arbitrate must be founded in a contract, must first decide the validity of the document on which his jurisdiction rests.

57. "It is the arbitrator's construction which was bargained for; and so far as the arbitrator's decision concerns construction of the contract, the courts have no business overruling him because their interpretation of the contract is different from his." United Steelworkers v. Enterprise Wheel \& Corp. supro note 54 at 599 . See also Wellington, Judicial Review of the Promise to Arbitrate, 37 N.Y.U.L. REv. 471, 476-33 (1962).

58. In a somewhat analogous situation, a judge's financial interest in the outcome of the case was sufficient to render his determination unconstitutional. See Tumey v. Ohio, 273 U.S. 510 (1927). But it might be argued that any decision by an arbitrator, under this rationale, would be open to suspicion due to the potential fee riding on the outcome. In a situation like that in Fibreboard Paper Products Corp. v. NLRB, 379 U.S. 203 (1964), for example, an arbitrator's decision as to the propricty of contracting out in effect vould also determine whether he was to be the recipient of fees over an extended period of time. For if the arbitrator finds that contracting out is not within management's prerogative, every time a dispute concerning contracting out arises in the futurc, he is likely to hear it as it is prosecuted through the grievance and arbitration procedure. A distinction can be drawn, however, between the self interest of a judge and that of an arbitra. 
Finally, a recent Supreme Court decision, John Wiley and Sons $v$. Livingston, 59 seems to support the argument that "jurisdictional arbitrability" will rarely, if ever, exist. That case involved the effect of a corporate merger on the arbitration provisions of a collective bargaining agreement between the predecessor corporation and a union. The latter sought to compel arbitration with the successor corporation to resolve questions of seniority and pensions resulting from the merger. The corporation claimed that the arbitration provisions were no longer effective. A unanimous Court held Wiley bound to arbitrate on grounds of national labor policy. In so doing, it was clearly stated that the court, not the arbitrator, was to determine the arbitration agreement's survival after the merger. ${ }^{60}$ Similarly, in cases where the existence of an agreement is at issue, it seems that the court would also reserve to itself the decision of the arbitrator's jurisdiction. ${ }^{01}$

tor. In the former case, the parties have no choice over the tribunal before which they appear, while in the latter, the parties select the arbitrator fully cognizant of his financial stake. For a discussion of this difference see Shulman, Reason, Contract, and Law in Labor Relations, 68 HARv. L. REv. 999, 1016 (1955).

59. 376 U.S. 543 (1964). See generally Note, 73 YALE L.J. 1459 (1964).

60. 376 U.S. at 547.

61. The case for jurisdictional arbitrability is not, however, without some support. Although the parties have not clearly consented to the agreement in question, they may have consented by implication to arbitrate disputes about its existence. Either the past history or the context of the parties' bargaining might indicate an acceptance of arbitration as the means for determining the formation of the contract. If, for example, the collective agreement at issue were one of a series in which the parties had always pro. vided a broad arbitration clause, it could be argued they intended to submit questions of contract formation to an arbitrator. The series might be temporal, involving a number of agreements over a period of time with identical arbitration provisions. Or the series might be spatial in that a number of different agreements are signed at the same time, each containing the same arbitration provision. Finally, multi-cmployer bargaining might also indicate acceptance if the master agreement and the individual agrecments reached between the union and the employers all contain identical arbitration provisions. In cach of these cases, the arbitration clause in the other agreements in the serics afford quantitative support for an inference that the parties are committed to arbitration in the agrec. ment in question. Furthermore, if the parties had often submitted to arbitration disputes arising in periods when there was no labor agreement in effect, there would be addl. tional support for the proposition that the arbitrator's jurisdiction is independent of the contract which he is called upon to adjudicate. Moreover, if these arguments were accepted, a court could refer the question of formation to the arbitrator, an individual who is presumably more familiar with the practices of the parties and with labor relations in general. See United Steelworkers v. Warrior \& Gulf Nav. Co., 363 U.S. 574, 581-82 (1960) for a traditional statement on the peculiar competence of the arbitrator. But see Hays, The Future of Labor Arbitration, 74 YALE L.J. 1019, 1084-85 (1965), where the author argues that in fact the arbitrator may often lack unique knowledge, insight or expertise.

Regardless of these arguments favoring jurisdictional arbitration, its propricty is by no means clear. Two reasons militate against allowing the arbitrator to decide the issue 
When arbitration is unavailable to a court it must develop its own rules for 301 disputes. ${ }^{62}$ There are several factors of which a court must take account. Since the law of labor agreements is obviously related to general contract doctrine, ${ }^{63}$ the first prerequisite to creating such law is an understanding of that doctrine. Contract principles may never be applied in the abstract; they are instead root conceptions which must be selected and modified in accordance with the context in which the parties bargain. ${ }^{64}$ For example, the law applicable to negotiable instruments is unlikely to be suited for collective bargaining agreements, although both are considered contracts. Superimposed on the negotiations leading to the latter is an extensive set of compulsory national regulations. ${ }^{65}$ The notion of freedom of contract, which has one meaning in commercial law, has a very different mean-

of the formation of the contract in a case like Genesco. First, a judge would be going beyond present law if he referred such an issue to an arbitrator. John Wilcy \& Sons v. Livingston, 376 U.S. 543 (1964), indicates the outer limits on the substantive determinations an arbitrator can properly make and that case seems to preclude jurisdictional arbitration. Second, Genesco was seeking damages, not submission of the dispute to arbitration. Since a request for arbitration was not before the appellate court, there would be little opportunity for it to make such an award.

62. This conclusion sheds light upon Judge Friendly's distinction between formation and interpretation. Instead of serving as a vehicle to determine when to refer to NLRB decisions, the distinction is relevant for deciding when the court itself must develop federal law based on national labor policy without the aid of arbitation.

63. The role played by general contract doctrine in adjudicating disputes concerning collective bargaining agreements has been considered by many commentators. See generally Cox, The Legal Nature of Collective Bargaining Agreements, 57 AIIci. Lo. REv. 1 (1958); Summers, Judicial Review of Labor Arbitration or Alice Loohing Through the Glass, 2 Buffalo L. REv. 1, 19-20 (1952); Wellington, Judicial Review of the Promise to Arbitrate, 37 N.Y.U.L. REV. 471, 475 (1962).

64. According to Professors Kessler and Sharp

a monistic approach serves only to distort the real role which contract has played in the evolution of our society. It results in more or less lifeless abstractions and achieves at best a "formal," but not a "substantive" rationality. A realistic understanding of the law of contracts can be achicred only through an awareness of the different functions fulfilled by the various kinds of contract in our society. This diversity of functions leads inevitably to a polytheism of ideals governing the law of contracts. A pluralistic approach may help to explain the many . . . inconsistencies ... which cannot be explained satisfactorily under a monistic approach.

KESSIER AND SHARP, CoNTRACIS 1 (1953). See also Kessler, Forces Shaping the Insurance Contract, The UNiversity of Chicaco LAw School Conference on Insurance 1, 6-7 (1954). Recently, the Supreme Court appears also to have recognized the unique trentment neces. sary for collective bargaining agreements. Mr. Justice Douglas stated:

In ous role of developing ... law to govern ... collective bargaining agrcements, we think special heed should be given to the context in which collective bargaining agreements are negotiated and the purpose which they are intended to serve.

United Steelworkers v. American Mfg. Co., 363 U.S. 564,567 (1980).

65. Chief among the statutes governing collective bargaining is the Labor Management Relations Act (Taft-Hartley Act), 61 Stat. 136 (1947), 29 U.S.C. $§ 141$ (1984). 
ing in light of the duty to bargain imposed by the LMRA. ${ }^{80}$ This cluty differentiates labor agreements from other contracts because it reflects a policy of forcing the parties to come together and negotiate. An even more fundamental difference between labor agreements and other contracts is that in the former the parties are seeking to direct the course of a relationship which may last over an extended period of time. To achieve this end successfully requires a good deal of flexibility, so that the inevitable problems that arise from day to day can be disposed of with a minimum of friction and delay. As a result, the parties will often consent to be bound by a collective bargaining agreement even though they do not see eye to eye on every issue. ${ }^{07}$

Thus, the standards for determining a meeting of the minds for collective bargaining agreements may not be found by a resort to Judge Friendly's "ordinary principles of contract." Although his principles, applied in the abstract, may have pointed to the absence of a contract in Genesco, a consideration of the practices of the particular industryos may have pointed to a contrary result. For example, if the court found that the contested conditions precedent were rarely included within collective agreements, there would arise an inference that the union consented to the contract as written. This inference would be strengthened by the parties' agreement to arbitrate issues related to the contract. $^{.99}$ For an arbitration provision demonstrates the parties' in-

66. Labor Management Relations Act, 61 Stat. 141 (1947), 29 U.S.C. $\$ \$ 158(\mathfrak{a})(5),(b)(8)$ (1964). See also Summers, Individual Rights in Collective Agreements and Arbitration, 87 N.Y.U.L. REv. 362 (1962), where the author states that "The freedom to agrce . . . is not absolute, for there is a competing concern for the rights of individual employecs who are governed by the collective agreement." Id. at 362 .

67. There are likely to be some matters about which parties will be unable to agrec in negotiating any contract. This situation might occur in employment contracts, requirements contracts, contracts for extended periods of time, as well as labor agreements. Yot an agreement may still be reached if there is concurrence on most significant matters. The extent to which unanimity is present will largely be a matter of degrec, varying with the complexity of the relationship. See Shulman, supra note 58, at 1003.05.

68. Such an investigation can be undertaken on a fairly objective level. In the Fibre. board case, the Court resorted to "industrial practices in this country. Whilc not determinative, it is appropriate to look to industrial bargaining practices in appraising the propriety of including a particular subject within the scope of mandatory bargaining." 379 U.S. 203, 211 (1964). It might be contended that only the Board has the expertise to undertake this kind of investigation. But as Professor Sovern emphatically argued, notions of primary jurisdiction, often based on the greater expertise of an administrative agency, have no place in $\S 301$ actions. See note 23 supra. This contention seems to warrant the conclusion that courts will necessarily have to develop the requisite expertise.

69. The arbitration provision between Genesco and the union reads in part "Any question in dispute between the parties arising out of or in relation to this agrcement shall be adjusted. ..." $230 \mathrm{~F}$. Supp. at 925 n.1. Clearly, the question of the place of manufacture is one "arising out of or in relation to" the agrcement. Morcover, the no 
tent to be bound even in the absence of unanimity on all issues at the time the bargain is struck. ${ }^{\text {To }}$

But the courts must do more than apply contract principles, even principles sensitive to the context of labor relations in which they operate. Lincoln Mills requires the courts to go further and, in fashioning contract law, promote national labor policies. Chief among these policies is the promotion of collective bargaining. Support for this contention can be found in both the original Wagner Act ${ }^{i 1}$ and subsequent Taft-Hartley ${ }^{22}$ and Landrum-Griffin Amendments, ${ }^{\text {i3 }}$ all of which sought to encourage unionization ${ }^{74}$ and to equalize the strength of labor and management so that they might bargain together meaningfully. The desire to afford individuals the freedom to regulate their dealings with one another, which constitutes the foundation of much of the doctrine of contract law, also underlaid the congressional choice of collective bargaining as the means to regulate the national labor market. ${ }^{75}$ One of the other prominent strains of labor policy is the desire to preserve labor peace. ${ }^{i 6}$ Initially, Congress sought to prevent bloodshed and violence. Now, however, the aim is to prevent strikes, boycotts, picketing and other types of concerted activity which may have an adverse effect on the national economy and breed animus

strike clause prohibits any "slowdown, strike or stoppage of work . . . pending the determination of any complaint. . . Ibid. These clauses add force to the contention that arbitration of the disputed matter was appropriate and that an agreement was in fact reached.

70. See Shulman, supra note 58, at 1007.

71. 49 Stat. 449 (1935).

72. Labor Management Relations Act, 61 Stat. 136 (1947), 29 U.S.C. $\S 141$ (1964).

73. Labor Management Reporting and Disclosure Act (Landrum-Grifin Act), 73 Stat. 541 (1959), 29 U.S.C. \$ 158 (1964).

74. The central provisions of the LMRA which serve to promote unionization are those guaranteeing the right of employees to organize and affording the majority union the status of exclusive representative of all the employees in a bargaining unit. Labor Management Relations Act, 61 Stat. 140, 143 (1947), 29 U.S.C. $\$ \S 157,159$ (a) (1964). Sec also Summers, American Legislation for Union Democracy, 25 MOdERN L. REv. 273, 277 (1962).

75. Alternatives to private ordering based on collective bargaining were two-foldindividual bargaining with management or government dictation of terms and conditions. The former mode of regulating the labor market was undesirable for it had produced many of the evils which prompted the agitation for change leading to the Wagner Act. See Bernsten, The New Deal Colrective Barganing Policy 7-14 (1950). The latter was also undesirable for it might open the door to government control of the unions. See S. REP. No. 105, 80th Cong., Ist Sess. 2 (1947); S. REP. No. 187, 86th Cong., Ist Sess. 7 (1959).

76. See S. REP. No. 105, supra note 75, at 2. See also Keyserling, The W'agner Act: Its Origin and Current Significance, 29 GEO. WASH. L. REV. 199, 216 (1960). 
between employers and employees. ${ }^{77}$ Finally, national labor policy seeks to ensure an individual's right to participate in decisions affecting his employment. ${ }^{78}$

Although these diverse components of labor policy can be isolated and identified, labor policy is usually advanced by a decision which places primary emphasis on the facilitation of the collective bargaining process. ${ }^{79}$ The assumption seems to be that maintenance of labor peace is promoted by allowing labor and management to make their own decision concerning their continuing relationship. Moreover, collective bargaining is necessary for industrial democracy since it assures to the membership of the union a significant voice in any bargain that is struck. And, of course, promoting collective bargaining encourages unionization by elevating the status of the union.

Had Judge Friendly followed the proper procedure in Genesco, he would not have relied upon his "ordinary" contract principles but would have sought a solution which promoted the collective bargaining process. By ruling that no agreement had been reached, ${ }^{80}$ in effect he required that the parties provide in the written instrument for all possible disputes which might arise between them. Without such express provisions neither party could, after the Genesco decision, be sure that the other would not claim it had made an oral reservation at the time of contracting. Although forcing parties to provide for all possible contingencies may be appropriate in some contractual situations, it is unsuitable for collective bargaining. At the time of the bargaining sessions labor and management have before them a potentially endless number of substantive issues. Requiring each to be disposed of in the labor contract would unduly prolong the bargaining, with the attendant effect of lengthening the work stoppage called to reinforce bargaining positions. Moreover, such a requirement fails to acknowledge the arbitration mechanism, present in virtually every labor contract, which provides for the resolution of disputes during the course of the agreement. The widespread use of arbitration indicates the need for flexibility in framing collective bargaining agreement. ${ }^{81}$

Perhaps the adverse effect which Genesco had on the collective bargaining process could be justified if the decision substantially advanced other policies of the labor laws. ${ }^{82}$ Arguably the Genesco deci-

77. See Labor Management Relations Act, 61 Stat. 136 (1947), 29 U.S.C. $\$ 141$ (1964).

78. See Summers, supra note 74, at 275.

79. See "Findings and Policy" NLRA, 49 Stat. 449-50 (1935), 29 U.S.C. $\S 151$ (1964).

80. 341 F.2d at 486.

81. See Shulman, supra note 58, at 1004 .

82. There are circumstances in which these other goals cannot be achieved through 
sion was in accord with the requirements of advancing labor peace, for the decision prevented the union from being forced to work under a contract with which it was dissatisfied. Employees who must return to work under such conditions might engage in practices throughout the contract term that disrupt production and harass management. The prospect of this beneficial effect is outweighed by the certainty of the harmful effect already mentioned. Similarly, Judge Friendly's decision cannot be justified by its impact upon industrial democracy or unionization. These two strains of labor policy are present in the case only to the extent that they are associated with the promotion of collective bargaining, which, as already shown, is undermined by the decision. Thus, had Genesco been decided by considering the dictates of national labor policy, a different result would have been reached.

Although the analysis of Genesco has dealt with contract formation, the approach suggested can be used to resolve questions of interpretation as well. What commends this means of adjudicating section 301 cases is the way in which national labor policy is able to play the central role in deciding the controversy. Instead of relying upon an abstract contract principle, a specific solution to a particular case is sought, and a federal substantive rule is used to decide the case. As a consequence, the constitutional problems raised by Lincoln Mills are satisfied. In addition, an analytical framework is established that enables the judiciary properly to face the policy decisions section 301 demands. Although the task which judges must assume is a difficult one, it cannot be avoided, for each case decided under that section has an inevitable effect upon labor-management relations. Unless courts use an appropriate methodology, they will continue to define the rights and obligations of parties to collective agreements in a haphazard fashion. Collective bargaining and national labor policy will suffer as a consequence.

reliance upon the collective bargaining process. A court in such cases must weigh the impact of its decision upon collective bargaining against the impact upon labor peace. industrial democracy or some other goal. One situation in which a tension is evident between the goals of preserving labor peace and promoting collective bargaining involves "hot cargo" clauses. These provisions require that a consenting employer not handle goods made in a non-union shop. In effect, they aid the union in bringing pressure on a non. union employer through the employer who has agreed to the clause. If the provision was freely arrived at, the promotion of collective bargaining would seem to point to its recognition and validity. But because the enforcement of the clauses tends to expand the area of industrial strife, must like a secondary boycott, Congress has made the negotiation of such agreements an unfair labor practice. 73 Stat. 543 (1959), 29 U.S.C. $\S 158(c)$ (1964). See also Wellington, Freedom of Contract and the Collective Bargaining Agreement, 112 U. PA. L. REv. 467,468 (1964). 


$$
\text { . }
$$

